\title{
UPAYA MENINGKATKAN KOMPETENSI PEDAGOGIK BERTANYA MELALUI SUKA TANYA BAGI GURU YANG MENGAJAR PESERTA DIDIK BARU DI SMA NEGERI 1 DUSUN SELATAN.
}

\author{
Oleh: Heri Purwanto*
}

\begin{abstract}
ABSTRAK
Kompetensi Pedagogik merupakan kompetensi profesional guru, termasukkemampuan komunikasi dalam proses pembelajaran yang interaktif, baik antara guru-peserta didik, peserta didik-guru maupun peserta didik-peserta didik dan diciptakan secara kondusif melalui penerapan teknik bertanya.Tetapi fakta di SMA Negeri 1 Dusun Selatan terutama kelas X pembelajaran berlangsung monoton, interaksi kelas minimal dan didominasi oleh guru sehingga dirasakan perlu dilakukan Supervisi Akademik Teknik Bertanya (Suka Tanya) serta untuk mengetahui tingkat keberhasilannya diobservasi dengan penelitian tindakan sekolah.

Tujuan Penelitian Tindakan Sekolah (PTS) ini untuk : (1) mengetahui apakahSuka Tanya dapat meningkatkan kompetensi pedagogik bertanya bagi guru yang mengajar peserta didik baru SMA Negeri 1 Dusun Selatan dan (2) bagaimana langkah-langkah agar Suka Tanya dapat meningkatkan kompetensi pedagogik bertanya bagi guru yang mengajar peserta didik baru SMA Negeri 1 Dusun Selatan.

Penelitian ini merupakan jenis penelitian tindakan dimana dilakukan tindakan berupa supervisi akademik untuk meningkatkan kompetensi pedagogik bertanya bagi guru SMA Negeri 1 Dusun Selatan. Penelitian dilaksanakan dalam dua siklus yang dibagi empat tahap yaitu: (1) perencanaan, (2) pelaksanaan, (3) observasi dan (4) refleksi, berfokus untuk memperoleh data interaksi kelas dan persepsi peserta didik dalam proses pembelajaran. Analisis data dengan metode deskriptif untuk menguraikan secara komprehensif proses dan hasil penelitian.

Hasil penelitian menunjukkan supervisi akademik teknik kelompok dengan jenis kegiatan pertemuan (meeting) ditambah latihan membuat pertanyaan ranah kognitif tingkat tinggi dapat meningkatkan kompetensi pedagogik bertanya bagi guru yang mengajar peserta didik baru di SMA Negeri 1 Dusun Selatan dengan indikator meningkatnya: (a) interaksi pembelajaran baik dari guru-peserta didik, peserta didikguru, peserta didik-peserta didik, (b) kemampuan guru dalam teknik bertanya, (c) meningkatnya kompetensi membuat pertanyaan dalam ranah kognitif lebih tinggi dan (d) persepsi positif peserta didik terhadap proses pembelajaran yang menyenangkan. Supervisi akademik dapat dioptimalisasi dengan pemisahan kelompok dan latihan bertanya sesuai karakter rumpun mata pelajaran IPA dan IPS.
\end{abstract}

Berdasarkan kesimpulan hasil penelitian disarankan kepada guru SMA Negeri 1 Dusun Selatan untuk meningkatkan penguasaan dan menerapkan teknik bertanya 
dalam proses pembelajaran dan kepada pihak lain untuk melakukan penelitian tindakan yang relevan untuk meningkatkan kompetensi professional guru.

\section{Kata Kunci : Kompetensi Pedagogik Guru, Teknik Bertanya, Supervisi Akademik}

\section{PENDAHULUAN}

Kompetensi Pedagogik merupakan salah satu dari lima kompetensi utama pada kinerja profesi guru. Salah satu komponen dalam kompetensi ini adalah kemampuan pengelolaan kelas.Teknik bertanya adalah salah satu faktor yang sangat menunjang pengelolaan kelas yang baik. Proses pembelajaran yang baik ditunjukkan dengan keaktifan kelas yang interaktif baik antara guru-peserta didik, peserta didik-guru maupun peserta didikpeserta didik. Interaksi akan berlangsung dengan baik apabila guru menerapkan teknik bertanya.

Guru SMA Negeri 1 Dusun Selatan berjumlah 51 (lima puluh satu) orang, terdiri dari 44 (empat puluh empat) guru PNS, 7 (tujuh) orang guru tidak tetap. Dalam pengamatan sepintas masih terpantau sebagian besar melakukan proses pembelajaran dengan metode ceramah, dan cenderung cepat keluar ruangan pada saat jam pelajaran selesai dan diiringi kegaduhan penuh kegirangan peserta didik. Setelah diamati dalam Penilaian Kinerja Guru formatif ratarata dalam satu kegiatan pembelajaran 19,7 kali interaksi, terlebih pada kelas $\mathrm{X}$ hanya terjadi rata-rata 15,6 interaksi dalam tiap tatapmuka. Kemungkinan peserta didik yang baru mengenal lingkungan sekolah memerlukan adaptasi pada jenjang pendidikan yang lebih tinggi. Dalam wawancara dengan peserta didik kelas $\mathrm{X}$ secara acak di 8 kelas berbeda, dari jumlah peserta didik 24 orang, ternyata lima belas orang mengaku tidak pernah atau sangat jarang bertanya, tujuh orang mengaku cukup sering bertanya dan dua orang menyatakan lebih sering bertanya untuk mengonfirmasi ucapan atau tulisan guru yang kurang jelas bukan pertanyaan atau tanggapan mengenai substansi materi pelajaran.

Idealnya proses pembelajaran harus berlangsung secara aktif, interaktif dan menyenangkan. Pemerintah melalui Kementrian Pendidikan dan Kebudayaan (Kemendikbud) telah melakukan sosialisasi dan pelatihan PAIKEM. Ketrampilan guru akan lebih optimal apabila didukung dengan penguasaan dan penerapan teknik bertanya dalam pembelajaran. Pembelajaran yang aktif, interaktif dan menyenangkan akan membangun karakteristik positif peserta didik. Hal ini akan mengembangkan rasa percaya diri, berpikir kritis, kecakapan berkomunikasi dan menghargai perbedaan pendapat. Karakter tersebut sangat diperlukan dalam menghadapi hidup penuh tantangan persaingan global secara wajar dan elemen penting dalam kehidupan kebinekaan 
bangsa Indonesia.Dengan menguasai dan menerapkan teknik bertanya diharapkan interaksi tiga arah yakni antara guru-peserta didik, peserta didik-guru maupun peserta didikpeserta didik dapatlebih ditingkatkan.Hal permasalahan relevan dan penting memberikan pemahaman kepada seluruh guru tentang teknik bertanya dalam pembelajaran.Memperhatikan latar belakang di atas maka kepala sekolah memutuskan untuk memberikan supervisi akademik kepada guru yang mengajar peserta didik baru mengingat

1. pada kelas ini interaksi teramati paling minimal;

2. peserta didik masih memerlukan adaptasi dengan lingkungan baru pada jenjang sekolah yang lebih tinggi;

3. paling strategis mengingat kelas X akan membawa iklim dan kebiasaan interaktif di kelas-kelas selanjutnya;

Tindakan supervisi akademik yaitu teknik kelompok dengan cara rapat (meeting) disebut Supervisi Akademik Teknik Bertanya (Suka Tanya) untuk dapat meningkatkan penguasaan dan pemahaman guru khusunya kelas X SMA Negeri 1 Dusun Selatan tentang teknik bertanya khususnya dan kompetensi pedagogik pada umumnya.

\section{Rumusan Masalah}

Dengan memperhatikan latar belakang di atas maka dirumuskan masalah penelitian sebagai berikut :

1. ApakahSuka Tanya dapat meningkatkan kompetensi pedagogik bertanya bagi guru yang mengajar peserta didik baru di SMA Negeri 1 Dusun Selatan?

2. Bagaimanakah langkahlangkah Suka Tanya sehingga guruyang mengajar peserta didik baru di SMA Negeri 1 Dusun Selatan dapat menerapkan kompetensi pedagogik bertanya?

\section{METODOLOGI PENELTIAN}

Subyek penelitian ini adalah guru yang mengajar peserta didik baru tahun pelajaran 2015/2016 SMA Negeri 1 Dusun Selatan berjumlah 17 (ttujuh belas) orang merepresentasikan tujuh belas mata pelajaran yang harus ditempuh oleh kelas $\mathrm{X}$ pada Kurikulum Tingkat Satuan Pelajaran (2006), terdiri dari empat belas orang guru PNS dan tiga orang guru tidak tetap.

Penelitian dilaksanakan di SMA Negeri 1 Dusun Selatan, Kabupaten Barito Selatan, Provinsi Kalimantan Tengah. Lokasi sekolah di jalan Ki Hajar Dewantara Buntok, merupakan salah satu jalan protokol berdekatan dengan pasar dan jalur utama lalulintas perekonomian daerah. SMA Negeri 1 Dusun Selatan beroperasi pada pagi hari , mulai jam 06.30 WIB sampai jam 13.00 WIB, dengan jumlah peserta didik 752 
orang, terbagi dalam dua puluh empat rombongan belajar.

Penelitian dilaksanakan pada semester I (gasal) tahun pelajaran 2015/ 2016 yang terbagi dalam : (1) persiapan penelitian 2 minggu ( Agustus 2015 ), (2) pelaksanaan penelitian 8 minggu ( AgustusOktober 2015 ), (3) penyusunan laporan 2 minggu ( Oktober 2015 )

\section{B. Prosedur Penelitian}

1. Persiapan

a. menyusun jadwal penelitian

b. memilih dan mengkomunikasikan rencana penelitian dengan kolaborator

c. membuat media dan mempesiapkan bahan supervisi akademik

d. membuat instrumen pengumpul data

\section{Tindakan}

Melaksanakan Suka Tanya bagi guru yang mengajar peserta didik baru pada minggu ke 2 Agustus dan minggu 4 Agustus 2015 :

a. Teknik Supervisi Akademik dengan Teknik Kelompok

b. Jenis Kegiatan melalui Rapat atau Pertemuan (meeting)

c. Cara penanaman kemampuan teknik bertanya dengan sosialisasi dan latihanmembuat pertanyaan yang baik.

d. Media yang digunakan $L C D$ Proyektor dengan penayangan power point konten teknik bertanya yang baik.

\section{Pengamatan Penelitian}

Penelitian akan dilaksanakan dalam dua siklus, yaitu :

a. tahap siklus meliputi : perencanaan, (2) pelaksanaan, (3) observasi dan (4) refleksi, menekankan pada pengamatan adanya perubahan agar guru yang mengajar peserta didik baru menerapkan teknik bertanya dalam proses pembelajaran.PTK

sebagaimana dinyatakan oleh Kemmis dan Mc Taggart (dalam Yatim Riyanto, 2001) merupakan penelitian yang bersiklus, yang terdiri dari rencana, aksi, observasi, dan refleksi yang dilakukan secara berulang, hal ini dapat digambarkan sebagai berikut:

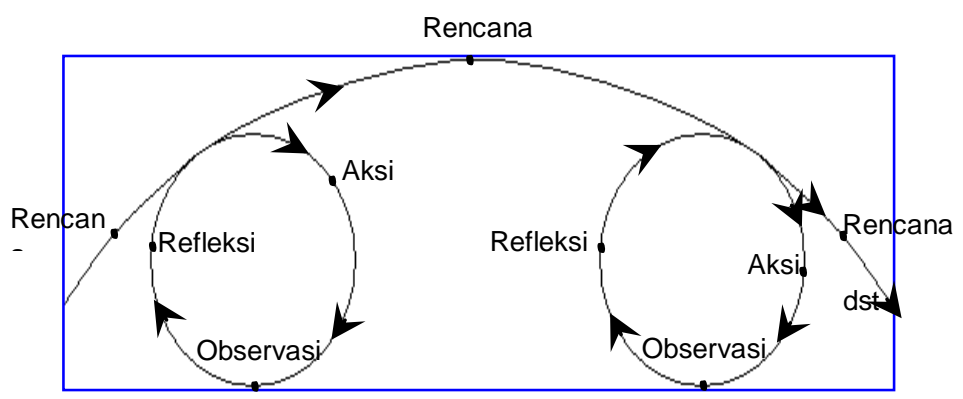

Gambar 3.1. Alur siklus penelitian tindakan

b. Kolaborator yakni anggota Tim Pengembang SMA Negeri 1 Dusun pada saat guru melaksanakan tatap muka dalam proses pembelajaran, bagian yang menjadi perhatian adalah : (1) interaksi dalam pembelajaran, (2) penerapan teknik 
bertanya dan (3) persepsi peserta didik terhadap proses pembelajaran dengan penerapan teknik bertanya.

\section{Indikator Keberhasilan Tindakan}

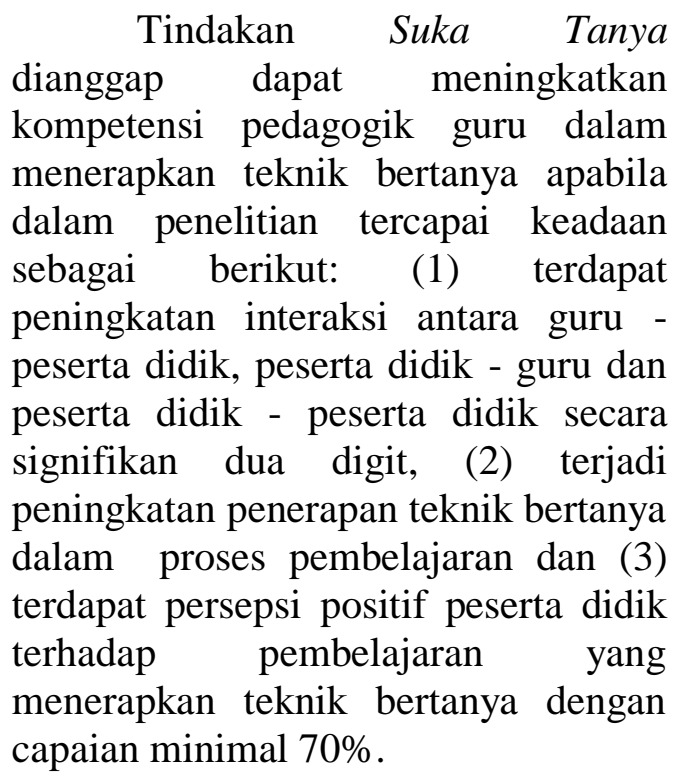

\section{HASIL DAN PEMBAHASAN}

\section{A. Hasil Peneliatian}

\section{Siklus I}

Hasil tindakan yang ditunjukkan guru dalam pembelajaran sebagaiamana tujuan penelitian yang diukur dengan indikator keberhasilan merujuk pada interaksi tiga arah antara : (1) gurupeserta didik (Guru bertanya kepada peserta didik, Guru menanggapi jawaban peserta didik, Guru memberi pujian kepada peserta didik), (2) peserta didik-guru (Peserta didik menjawab pertanyaan guru, Peserta didik bertanya kepada guru) dan (3) peserta didik-peserta didik (Peserta didik menanggapi pertanyaan/ jawaban peserta didik lain). Hasil rekapitulasi arah interaksi seperti di bawah ini :
Tabel 4.5. Persentase arah interaksi dalam proses pembelajaran

\begin{tabular}{|c|c|c|c|}
\hline \multirow[t]{2}{*}{ No } & \multirow{2}{*}{$\begin{array}{c}\text { Arah } \\
\text { Interaksi }\end{array}$} & \multicolumn{2}{|c|}{$\begin{array}{l}\text { Rekapitulasi } \\
\text { Interaksi : }\end{array}$} \\
\hline & & Jumlah & Presentasi \\
\hline 1 & $\begin{array}{l}\text { Guru - } \\
\text { Peserta } \\
\text { Didik }\end{array}$ & 351 & $55,54 \%$ \\
\hline 2 & $\begin{array}{l}\text { Peserta } \\
\text { Didik - } \\
\text { Guru }\end{array}$ & 222 & $35,12 \%$ \\
\hline 3 & $\begin{array}{l}\text { Peserta } \\
\text { Didik - } \\
\text { Peserta } \\
\text { Didik } \\
\end{array}$ & 59 & $09,34 \%$ \\
\hline & Jumlah & 632 & $100,00 \%$ \\
\hline
\end{tabular}

menunjukkan indikator keberhasilan adalah kemampuan guru dalam bertanya yaitu : (1) pertanyaan bersifat terbuka diamati oleh kolaborator dengan pernyataan negatif "Peserta didik menjawab serentak (koor)”, (2) pertanyaan bersifat menyeluruh, tidak menunjuk peserta didik terlebih dahulu untuk menjawab sehingga peserta didik lain dalam keadaan siaga (on task) diamati dengan lembar observasi dengan pernyataan positif "Pertanyaan guru tertuju pada seluruh ruangan”, (3) guru memberi penguatan diobservasi dengan pernyataan positif "Guru memberi pujian kepada peserta didik", (4) menguasai teknik bertanya diamati dengan pernyataan negatif "Guru mengulang pertanyaan sendiri/ jawaban peserta didik", dan (5) guru memberi waktu tunggu dengan pernyataan positif "Ada waktu tunggu antara pertanyaan guru dengan jawaban peserta didik dan antara 
jawaban peserta didik dengan tanggapan guru".

Pernyataan positif diberi skor untuk jawaban tidak pernah $(\mathrm{TP})=1$, jarang $(J R)=2$, sering $(S R)=3$, dan selalu $(\mathrm{SL})=4$, sedangkanpernyataan negatif diberi skor untuk jawaban tidak pernah $(\mathrm{TP})=4$, jarang $(\mathrm{JR})=3$, sering $(\mathrm{SR})=2$, dan selalu $(\mathrm{SL})=1$. Nilai keseluruhan guru dalam suatu kemampuan bertanya adalah jumlah skor seluruh guru dibanding jumlah skor maksimum $(17$ x $4=68)$ seluruh guru x 100. Rekapitulasi nilai kemampuan guru dalam bertanya seperti tabel :

Tabel 4.6. Prosentase penguasaan guru terhadap teknik bertanya

\begin{tabular}{|c|l|c|c|}
\hline No & $\begin{array}{l}\text { Kemampuan } \\
\text { Bertanya }\end{array}$ & $\begin{array}{c}\text { Pumlah } \\
\text { Skor }\end{array}$ & Nilai \\
\hline 1 & $\begin{array}{l}\text { Pertanyaan } \\
\text { bersifat } \\
\text { terbuka }\end{array}$ & 37 & 54,41 \\
\hline 2 & $\begin{array}{l}\text { Pertanyaan } \\
\text { bersifat } \\
\text { menyeluruh }\end{array}$ & 56 & 82,35 \\
\hline 3 & $\begin{array}{l}\text { Memberi } \\
\text { penguatan }\end{array}$ & 51 & 75,00 \\
\hline 4 & $\begin{array}{l}\text { Tidak } \\
\text { mengulang- } \\
\text { ulang } \\
\text { pertanyaan } \\
\text { sendiri/ } \\
\text { jawaban } \\
\text { peserta didik }\end{array}$ & 44 & 64,71 \\
\hline 5 & $\begin{array}{l}\text { Memberi } \\
\text { waktu } \\
\text { tunggu }\end{array}$ & 50 & 73,52 \\
\hline
\end{tabular}

Pertanyaan yang bermutu adalah yang menggali tingkat ranah kognitif yang tinggi. Hasil rekapitulasi menunjukkan bahwa pertanyaan guru masih berupa tagihan respon tingkat rendah $\mathrm{C} 1$ dan $\mathrm{C} 2$ hal ini sangat memerlukan perhatian mengingat soalsoal kekinian semisal bikinan PISA lebih menekankan penyelesaian atau jawaban pada ranah tingkat tinggi. Selengkapnya persentase ranah kognitif pertanyaan guru seperti tabel berikut:

Tabel 4.7. Persentase kategori rahnah kognitif penbelajaran yang menerapkan Teknik

Bertanya

\begin{tabular}{|c|c|c|c|c|r|}
\hline \multirow{2}{*}{ Kategori } & \multicolumn{5}{|c}{ Ranah kognitif pertanyaar } \\
\cline { 2 - 6 } & $\mathrm{C} 1$ & $\mathrm{C} 2$ & $\mathrm{C} 3$ & $\mathrm{C} 4$ & $\mathrm{C}$ \\
\hline Jumlah & 69 & 68 & 5 & 0 & 0 \\
\hline$\%$ & 48,59 & 47,89 & 3,52 & 0 & 0 \\
\hline
\end{tabular}

Respon peserta didik terhadap

proses pembelajaran merupakan bagian dari mutu pendidikan. Pembelajaran berlangsung berkualitas apabila peserta didik merespon pembelajaran secara positif , mampu mengembangkan kemampuan komunikasi, memotivasi dan menjadikan proses pembelajaran yang menyenangkan. Hasil respon peserta didik yang diperoleh dari kuesioner yang dibagikan secara acak kepada 30 orang dari kelas yang berbeda adalah sebagai berikut :

Tabel 4.8. Persentase Respon Peserta Didik Terhadap Pembelajaran yang 
Menerap kan Teknik

Bertanya

\begin{tabular}{|c|c|c|c|}
\hline \multirow{2}{*}{$\mathrm{N}$} & \multirow{2}{*}{$\begin{array}{c}\text { Respon peserta } \\
\text { didik terhadap } \\
\text { Pembelajaran }\end{array}$} & \multicolumn{2}{|c|}{ Persentasi } \\
\hline & & $\mathrm{Ya}$ & $\begin{array}{c}\text { Tida } \\
\text { k }\end{array}$ \\
\hline 1 & $\begin{array}{l}\text { Ada perubahan } \\
\text { penampilan } \\
\text { bapak/ibu guru } \\
\text { dalam } \\
\text { menyajikan } \\
\text { pelajaran }\end{array}$ & $\begin{array}{c}30,00 \\
\%\end{array}$ & $\begin{array}{c}70,00 \\
\%\end{array}$ \\
\hline 2 & $\begin{array}{l}\text { Pertanyaan yang } \\
\text { disampaikan } \\
\text { guru terdengar } \\
\text { dengan jelas ke } \\
\text { seluruh ruangan }\end{array}$ & $\begin{array}{c}90,00 \\
\%\end{array}$ & $\begin{array}{c}10,00 \\
\%\end{array}$ \\
\hline 3 & \begin{tabular}{lr}
\multicolumn{2}{l}{ Pertanyaan } \\
\multicolumn{2}{l}{ disampaikan } \\
guru & dengan \\
bahasa & yang \\
mudah & sehingga \\
dapat & saya \\
pahami & dengan \\
baik &
\end{tabular} & $\begin{array}{c}93,67 \\
\%\end{array}$ & $\begin{array}{c}6,67 \\
\%\end{array}$ \\
\hline 4 & $\begin{array}{l}\text { Saya dan teman- } \\
\text { teman lebih } \\
\text { termotivasi untuk } \\
\text { bertanya selama } \\
\text { pembelajaran } \\
\text { berlangsung }\end{array}$ & $\begin{array}{c}66,67 \\
\%\end{array}$ & $\begin{array}{c}33,33 \\
\%\end{array}$ \\
\hline 5 & $\begin{array}{l}\text { Saya diberi } \\
\text { waktu untuk } \\
\text { berpikir/menemu } \\
\text { kan jawaban } \\
\text { setelah guru } \\
\text { mengajukan } \\
\text { pertanyaan }\end{array}$ & $\begin{array}{c}96,67 \\
\%\end{array}$ & $\begin{array}{c}3,33 \\
\%\end{array}$ \\
\hline 6 & $\begin{array}{lr}\text { Jika saya } & \text { atau } \\
\text { teman } & \text { saya } \\
\text { menjawab } & \text { benar } \\
\text { maka } & \text { guru }\end{array}$ & $\begin{array}{c}80,00 \\
\%\end{array}$ & $\begin{array}{c}20,00 \\
\%\end{array}$ \\
\hline
\end{tabular}

\begin{tabular}{|c|c|c|c|}
\hline & $\begin{array}{l}\text { member pujian } \\
\text { dengan kata atau } \\
\text { isyarat }\end{array}$ & & \\
\hline 7 & $\begin{array}{l}\text { Jika ada yang } \\
\text { menjawab salah } \\
\text { guru } \\
\text { mengucapkan } \\
\text { kata/isyarat yang } \\
\text { menyakitkan }\end{array}$ & $\begin{array}{c}3,33 \\
\%\end{array}$ & $\begin{array}{c}96,67 \\
\%\end{array}$ \\
\hline 8 & $\begin{array}{l}\text { Penyampaian } \\
\text { bapak/ibu guru } \\
\text { dalam } \\
\text { menyajikan } \\
\text { pelajaran lebih } \\
\text { menarik/menyen } \\
\text { angkan }\end{array}$ & $\begin{array}{c}86,67 \\
\%\end{array}$ & $\begin{array}{c}13,33 \\
\%\end{array}$ \\
\hline
\end{tabular}

\section{Refleksi}

Secara umum tindakan supervisi akademik telah mencapai indikator keberhasilan tindakan yang diamati dari pembelajaran yang dilakukan guru dalam menerapkan teknik bertanya. Tetapi belum semua guru SMA Negeri 1 Dusun Selatan memperoleh pengetahuan dan penguasaan teknik bertanya, dari dua puluh orang guru, yang telah mengikuti sosialisasi baru enam belas orang. Hal ini disebabkan dua orang guru secara hampir bersamaan memohon ijin untuk cuti bersalin, satu orang menjadi panitia ulangan kenaikan kelas di sekolah induknya dan satu orang mengikuti diklat kompetensi guru.Diharapkan dalam supervisi akademik dan observasi pada siklus kedua seluruh guru dapat terlibat di dalamnya.

Guru telah menerapkan teknik bertanya dalam pembelajaran yang 
berarti telah memiliki sebagian dari kompetensi pedagogik. Hanya saja guru masih belum bisa mengoptimalkan pendapat dan tanggapan peserta didik untuk dijadikan bahan diskusi yang mendorong peserta didik yang lain untuk menyampaikan pendapatnya. Ini terlihat dari hasil observasi bahwa hampir untuk semua proses pembelajaran jumlah jawaban peserta didik relatif sama dengan jumlah pertanyaan guru, padahal guru dapat memperbanyak jawaban dan tanggapan peserta didik dengan jalan meminta peserta didik yang lain setuju atau tidak setuju dengan jawaban temannya. Terlihat guru sering menggunakan jawaban satu peserta didik untuk diarahkan mencapai substansi yang diinginkan.Kemungkinan hal ini disebabkan terpaku pada catatan alur bertanya yang dibawanya waktu mengajar yang diperoleh saat sosialisasi, sehingga ada urutan harus bertanya, menanggapi, memberi penguatan dan waktu tunggu dan seterusnya. Oleh karenanya dalam siklus ke dua akan dilakukan lagi supervisi akademik yang bertitik berat pada mengekplorasi jawaban dan tanggapan peserta didik.

Karakteristik pertanyaan dalam pembelajaran eksak dan sosial mungkin berbeda, sehingga diperlukan pendalaman lebih khusus pada masingmasing rumpun mata pelajaran. Jadi ada sedikit modifikasi pertemuan supervisi akademik pada siklus kedua yakni dipisahkan antara guru-guru yang mengampu mata pelajaran kelompok Matematika-IPA dan IPSBahasa. Sosialisasi dilaksanakan dua kali pertemuan, pertemuan pertama rumpun IPA sedangkan pertemuan kedua rumpun IPS.disini juga dipikirkan cara untuk memperbaiki mutu pertanyaan guru yang berkisar pada ranah $\mathrm{C} 1$ dan $\mathrm{C} 2$.

\section{Siklus II}

Interaksi tiga arah antara : (1) gurupeserta didik (Guru bertanya kepada peserta didik, Guru menanggapi jawaban peserta didik, Guru memberi pujian kepada peserta didik), (2) peserta didik-guru (Peserta didik menjawab pertanyaan guru, Peserta didik bertanya kepada guru) dan (3) peserta didik-peserta didik (Peserta didik menanggapi pertanyaan/ jawaban peserta didik lain), yaitu :

Tabel 4.13. Persentasi arah interaksi dalam proses pembelajaran

\begin{tabular}{|c|l|c|c|}
\hline \multirow{2}{*}{ No } & \multirow{2}{*}{$\begin{array}{c}\text { Arah } \\
\text { Interaksi }\end{array}$} & \multicolumn{2}{|c|}{ Interaksi : } \\
\cline { 3 - 4 } 1 & $\begin{array}{l}\text { Guru - } \\
\text { Peserta } \\
\text { Didik }\end{array}$ & 386 & $51,06 \%$ \\
\hline \multirow{2}{*}{2} & $\begin{array}{l}\text { Peserta } \\
\text { Didik - } \\
\text { Guru }\end{array}$ & 277 & $36,64 \%$ \\
\hline \multirow{2}{*}{3} & $\begin{array}{l}\text { Peserta } \\
\text { Didik - } \\
\text { Peserta } \\
\text { Didik }\end{array}$ & 93 & $12,30 \%$ \\
\hline \multicolumn{2}{|c|}{ Jumlah } & 756 & $100,00 \%$ \\
\hline
\end{tabular}

Kompetensi teknik bertanya guru yakni: (1) pertanyaan bersifat terbuka diamati oleh kolaborator dengan pernyataan negatif "Peserta 
didik menjawab serentak (koor)", (2) pertanyaan bersifat menyeluruh, tidak menunjuk peserta didik terlebih dahulu untuk menjawab sehingga peserta didik lain dalam keadaan siaga (on task) diamati dengan lembar observasi dengan pernyataan positif "Pertanyaan guru tertuju pada seluruh ruangan", (3) guru memberi penguatan diobservasi dengan pernyataan positif "Guru memberi pujian kepada peserta didik", (4) menguasai teknik bertanya diamati dengan pernyataan negatif "Guru mengulang pertanyaan sendiri/ jawaban peserta didik", dan (5) guru memberi waktu tunggu dengan pernyataan positif "Ada waktu tunggu antara pertanyaan guru dengan jawaban peserta didik antara jawaban peserta didik dengan tanggapan guru".

Sebagaimana pada silkus 1, pernyataan positif diberi skor untuk jawaban tidak pernah $(\mathrm{TP})=1$, jarang $(J R)=2$, sering $(S R)=3$, dan selalu $(\mathrm{SL})=4$, sedangkanpernyataan negatif diberi skor untuk jawaban tidak pernah $(\mathrm{TP})=4$, jarang $(\mathrm{JR})=3$, sering $(\mathrm{SR})$ $=2$, dan selalu $(\mathrm{SL})=1$. Nilai keseluruhan guru dalam suatu kemampuan bertanya adalah jumlah skor seluruh guru dibanding jumlah skor maksimum seluruh guru x 100 . Rekapitulasi nilai guru dalam bertanya tertera dalam tabel berikut :

Tabel 4.14. Prosentase penguasaan guru terhadap teknik bertanya

\begin{tabular}{|c|c|c|c|}
\hline \multirow{2}{*}{ No } & \multirow{2}{*}{$\begin{array}{c}\text { Kemampuan } \\
\text { Bertanya }\end{array}$} & $\begin{array}{c}\text { Jumlah } \\
\text { Skor }\end{array}$ & Nilai \\
\hline 1 & Pertanyaan & 46 & 67,65 \\
\hline
\end{tabular}

\begin{tabular}{|c|l|c|c|}
\hline 2 & $\begin{array}{l}\text { bersifat } \\
\text { terbuka }\end{array}$ & & \\
\hline 2 & $\begin{array}{l}\text { Pertanyaan } \\
\text { bersifat } \\
\text { menyeluruh }\end{array}$ & 53,82 \\
\hline 3 & $\begin{array}{l}\text { Memberi } \\
\text { penguatan }\end{array}$ & 53 & 77,94 \\
\hline 4 & $\begin{array}{l}\text { Tidak } \\
\text { mengulang- } \\
\text { ulang } \\
\text { pertanyaan } \\
\text { sendiri/ } \\
\text { jawaban } \\
\text { peserta didik }\end{array}$ & 48 & 70,59 \\
\hline 5 & $\begin{array}{l}\text { Member } \\
\text { waktu tunggu }\end{array}$ & 56 & 82,35 \\
\hline
\end{tabular}

Sedangkan sebaran ranah kognitif pertanyaan guru telah berkembang cukup baik pada tingkat C1 sampai dengan $\mathrm{C} 4$, belum teridentifikasinya tingkat $\mathrm{C} 5$ dan C6 menunjukkan bahwa tidak mudah membuat atau memberi pertanyaan pada ranah kognitif yang tinggi. Hasil persentase sebaran ranah kognitif pertanyaan tertera pada tabel berikut :

Tabel 4.15.Persentase kategori ranah kognitif pertanyaan guru yang

menerapkan teknik bertanya

\begin{tabular}{|c|c|c|c|c|c|c|c|}
\hline \multirow{2}{*}{$\begin{array}{c}\text { Kat } \\
\text { egor } \\
\text { i }\end{array}$} & \multicolumn{6}{|c|}{ Ranah kognitif pertanyaan guru } \\
\cline { 2 - 8 } & C1 & C2 & C3 & C4 & $\begin{array}{c}\text { C } \\
5\end{array}$ & $\begin{array}{c}\text { C } \\
6\end{array}$ & $\begin{array}{c}\text { Ju } \\
\text { mla } \\
\text { h }\end{array}$ \\
\hline $\begin{array}{c}\text { Jum } \\
\text { lah }\end{array}$ & 46 & 54 & 27 & 17 & 0 & 0 & 144 \\
\hline$\%$ & $\begin{array}{c}31 \\
9\end{array}$ & $\begin{array}{c}37 \\
, 5\end{array}$ & $\begin{array}{c}18 \\
7\end{array}$ & $\begin{array}{c}11 \\
, 8\end{array}$ & 0 & 0 & 100 \\
\hline
\end{tabular}




\begin{tabular}{|l|l|l|l|l|l|l|l|}
\hline & 4 & 0 & 5 & 1 & & & \\
\hline
\end{tabular}

Hasil respon peserta didik yang diperoleh dari kuesioner yang dibagikan secara acak kepada 30 orang dari kelas yang berbeda adalah sebagai berikut :

Tabel 4.16. Persentase Respon Peserta Didik Terhadap Pembelajaran yang Menerapkan Teknik Bertanya

\section{Refleksi}

Tindakan supervisi akademik pada siklus 2 meningkatkan pencapaian indikator keberhasilan guru dalam menerapkan teknik bertanya. Guru yang mengajar peserta didik baru SMA Negeri 1 Dusun Selatan yang memperoleh pengetahuan dan penguasaan teknik bertanya, sebanyak 17 (tujuh belas) orang . Guru telah menerapkan teknik bertanya dalam pembelajaran yang berarti telah memiliki sebagian dari kompetensi pedagogik. Meskipun ada peningkatan namun guru masih belum bisa mengoptimalkan pendapat dan tanggapan peserta didik untuk dijadikan bahan diskusi yang mendorong peserta didik yang lain untuk menyampaikan pendapatnya. Ini terlihat dari hasil observasi bahwa hampir untuk semua proses pembelajaran jumlah jawaban peserta didik relatif sama dengan jumlah pertanyaan guru, padahal guru dapat memperbanyak jawaban dan tanggapan peserta didik dengan jalan meminta peserta didik yang lain setuju atau tidak setuju dengan jawaban temannya, demikian juga guru masih menggunakan jawaban satu peserta didik untuk diarahkan mencapai substansi yang diinginkan. Oleh karenanya masih perlu penguatan dan latihan membuat pertanyaan yang bersifat terbuka dan mengekplorasi jawaban dan tanggapan peserta didik baik melalui supervise akademik maupun secara mandiri di sekolah. Karakteristik pertanyaan dalam pembelajaran eksak dan sosial terbukti memiliki kekhasan sendiri , sehingga diperlukan pendalaman dan latihan lebih khusus pada masing-masing rumpun mata pelajaran tersebut yang dapat dilakukan dengan guru serumpun mata pelajaran di sekolah atau guru yang satu mata pelajaran dari sekolah lain melalui MGMP masingmasing mata pelajaran .

\section{KESIMPULAN}

Berdasarkan hasil perhitungan dan analisis data dalam penelitian ini, dapat disimpulkan sebagai berikut:

1. Secara umum Suka Tanya dapat meningkatkan kompetensi pedagogik bertanya bagi guru yang mengajar peserta didik baru SMA Negeri 1 Dusun Selatan . Secara khusus Suka Tanya teknik kelompok dengan jenis kegiatan pertemuan (meeting) dapat meningkatkan:

a. interaksi pembelajaran baik dari guru-peserta didik, peserta didik-guru, peserta didikpeserta didik; 
b. kompetensi guru dalam penguasaan teknik bertanya;

c. kompetensi guru membuat pertanyaan dalam ranah kognitif yang lebih tinggi;

d. persepsi positif peserta didik terhadap proses pembelajaran yang menyenangkan.

2. Langkah-langkah agar Suka Tanya menjadikan guru yang mengajar peserta didik baru SMA Negeri 1 Dusun Selatan dapat menerapkan kompetensi pedagogik bertanya

a. sosialisasi konten menggunakan media power point dengan teknik

kelompok jenis kegiatan pertemuan (meeting);

b. latihan menyampaikan pertanyaan dengan ranah kognitif lebih tinggi;

c. supervisi dengan pemisahan kelompok dan latihan bertanya sesuai karakter rumpun mata pelajaran Matematika-IPA dan IPS-Bahasa.

\section{DAFTAR PUSTAKA}

Aqip, Z., dan Rohmanto, 2007, Membangun Profesionalisme Guru dan Kepala Sekolah, Bandung : Utama Widya.

Glickman,C.D.,Gordon,S.P., and RossGordon,JM.2007. Supervision and Instructional Leadership A Development Approach. Seventh Edition, Boston: Pearson.

Depdikbud.Direktorat Jenderal Pendidikan Dasar dan
Menengah.1991. Petunjuk Pembinaan Profesional Guru, Jakarta: Direktorat Pendidikan Menengah Umum.

Harahap, B.1983, Supervisi Pendidikan, Jakarta : Damai Jaya.

Indrayanto.2010. Supervisi Akademik (Online)

(http://id.shvoong.com/socialsciences/education/2025213supervisi-akademik/, diakses 09 Juni 2015)

Iryanti,P.2012. Teknik Bertanya Guru Matemetika (Online)

(http://p4tkmatematika.org/201

2/02/teknik-bertanya-gurumatematika/ diakses 09 Juni 2015)

Kemendikbud.2012. Supervisi Akademik, Bahan Diklat Penguatan Kemampuan Kepala Sekolah, Jakarta: PPTK BPSDMPK dan PMP.

Kemendiknas.2011. Pedoman Pelaksanaan Penilaian Kinerja Guru (PK Guru), Buku 2, Jakarta: Direktorat PPTK.

Mushofa, A.02 September 2010. Hakikat dan Teknik Bertanya dalam Pembelajaran (Online) ( http://Mashofa.wordpress.com diakses 09 Juni 2015)

Rudi.2012. Supervisi Akademik Merupakan Upaya Peningkatan Mutu Guru

(Online)(http://edukasi.kompasiana.co m/2012/03/06/supervisiakademik-merupakan-upayapeningkatan-mutu-guru/ diakses 09 Juni 2015) 
Sahertian , P. A.1981, Prinsip dan Teknik Supervisi Pendidikan, Surabaya : Usaha Nasional.

Sahertian , P. A. 2000, Supervisi Pendidikan, Jakarta : Rineka Cipta

Supriyono. 2012. Pengaruh Sistem Supervisi Akademik Pengawas Sekolah terhadap Profesionalisme Guru SMA Negeri 1 Padang Padi Lampung Tengah (Online) ( http://lontar.ui.ac.id/themes/libr i2/detail.jsp?id, diakses 12 Juni 2015)

Tim Pengembang SMAN 1 Tenjo.2011. Upaya Meningkatkan Kompetensi Guru dalam Menyusun Silabus dan RPP Melalui Supervisi Akademik Berkelanjutan di SAMN 1 Tenjo Kabupaten Bogor (Online)

(http://paismabogor.files.wordpress.co m/2011/04/laporan.pts.pdf. diakses 09 Juni 2015)

Zariant ,A.2012. Definisi KognitifAfektif dan Psikomotorik Online)

(http://abazariant.blogspot.co.id/2012/ 10/definisi-kognitif-afektifdan-psikomotor.html diakses 07 Juli 2015) 